MATEC Web of Conferences 47, 05025 (2016)

DOI: $10.1051 /$ matecconf/20164705025

(C) Owned by the authors, published by EDP Sciences, 2016

\title{
An Overview of Organic Waste in Composting
}

\author{
Aeslina Abdul Kadir ${ }^{1, a}$, Nur Wahidah Azhari ${ }^{1}$ and Siti Noratifah Jamaludin ${ }^{1}$ \\ ${ }^{1}$ Faculty of Civil and Environmental Engineering, Universiti Tun Hussein Onn Malaysia, 86400 Parit Raja, Johor, \\ Malaysia
}

\begin{abstract}
This paper reviewed studies on the composting process of organic waste. Organic wastes are wastes that easily biodegradable. These wastes are produced from many sources such as agricultural waste, market waste, kitchen waste, urban solid food wastes and municipal solid waste. Without proper management, these waste could create several environment problem. Therefore, composting is the best low cost alternative solution to overcome this problem. Composting method can degrade all types of organic wastes like fruits, vegetables, plants, yard wastes and others. The composition from organic waste that could be used as nutrients for crops, soil additive and for environmental management. However, many factors can contribute to the quality of the compost products as different types of organic wastes have different concentrations of nutrients, nitrogen, phosphorous and potassium $(\mathrm{N}, \mathrm{P}, \mathrm{K})$ which are the common macro nutrients present in fertilizers. The presences of heavy metals show how composts can be applied to soils without contributing any ill effect. In term of the factor affecting the composting process, temperature, $\mathrm{pH}$, moisture contents and carbon nitrogen ratio $(\mathrm{C}: \mathrm{N})$ are the main parameters that contribute to the efficiency of the composting process.
\end{abstract}

\section{Introduction}

In Malaysia, the percentage of organic waste in the environment was between 48 to $68 \%$ [1]. Due to the large amount of organic waste in the environment, it has become one of the main global issues. Among the various treatments in managing the organic waste such as the use of landfill and incineration, decaying organic wastes by using biological processes is considered as more suitable solution method [2,3]. Composting is one of low cost biological decomposition process. The composting process is circuited by microbial activity. The physical-chemical parameter affected by this process include temperature, aeration, moisture content, $\mathrm{C}: \mathrm{N}$ ratio and $\mathrm{pH}$ [4].

Composting is an alternative solid waste management system (SWM), it can be used for the recycling of organic matters into useful products. In addition, it can also be used to control the increase of waste [5]. This process is considered to be the most efficient, environmentally safe and most agronomically sound, where compost can be used as a soil conditioner, organic fertilizer as well as containing high nutrients for the soil [6]. The microbial community in compost, which are bacteria, fungi and worms can also stabilize the degradable organic matters.

Besides that, the characteristics of the microbial population depend on the substrate and physical conditions, which are the moisture, temperature and aeration of where composting take place. The performance of the composting process also will depend on the characteristics of the waste because

\footnotetext{
${ }^{a}$ Corresponding author : aeslina@uthm.edu.my
} 
composting is only suitable for waste that is biodegradable [7]. There are many advantages that can arise from composting, including the reduction of volume, weight and water content of the waste as well as producing inactive pathogenic organisms $[8,9]$. Therefore, the compost can contribute to the improvement of soil contents and nutrients required for harvesting plants, and will significantly reduce the use of synthetic fertilizers [10]. The application of compost can improve soil properties that are badly in need of renewal as it can increase the organic carbon contents in the soil. Meanwhile, compost also act as a soil intervention in improving soil structure, water infiltration rate, water holding capacity and tilth [12].

\section{Overview of Organic Waste in Composting}

The composting of organic waste in Malaysia is highly encouraged. As a huge amount of wastes are filling our overfilled landfills. Therefore, this paper will review composting as an alternative method for waste management. The physical and chemical properties of organic wastes during the composting processes had been discussed in details by many researchers. This paper will review studies on how the organic wastes were disposed using the composting method. The studies reviewed were divided into three classifications of organic wastes, which are agriculture waste, municipal solid waste and kitchen waste.

\subsection{Agriculture wastes}

Agricultural Wastes (AW) are wastes produced from agricultural activities in agricultural premises. Agricultural wastes are often managed poorly because of the limited access to disposal facilities, hence most of agricultural wastes are burned or incinerated. Taleb et al., [13] studied the compost of plant residues and sheep manure with soil (1:1). The compost pile was put in a box with the dimension of $1.7 \mathrm{~m} \times 5 \mathrm{~m} \times 5 \mathrm{~m}$. The initial temperature of the compost was $25^{\circ} \mathrm{C}$, the value increased after 30 days to $30^{\circ} \mathrm{C}$ but declined to $24^{\circ} \mathrm{C}$ in day 50 at the end of the composting process. The increasing of the temperature had affected the moisture content. The moisture content slowly decreased at the end of 50 days, the $\mathrm{pH}$ value also decreased from 8.38 to 6.02 . While for $\mathrm{N}, \mathrm{P}$ and $\mathrm{K}$ contents, $0.65 \%$, $0.00295 \%$ and $0.3640 \%$ were recorded at the end of the composting process. Unfortunately, the availability of $\mathrm{P}$ and $\mathrm{K}$ content was less compared to the compost fundamental by Washington State University (WSU).

Furthermore, Ch'ng et al. [14] studied the compost of pineapple leaves (PL) wastes. In this study, Polystyrene boxes were used. The ambient temperature was recorded between 25 to $32.5^{\circ} \mathrm{C}$. The compost seed, was a combination of PL $(3.5 \mathrm{~kg})$, chicken manure $(2.8 \mathrm{~L})$, chicken feeds $(350 \mathrm{~g})$ and molasses $(175 \mathrm{~g})$. Chicken manure and molasses were used as microbial seedings and to supply carbohydrates for the microbes. During the composting process, the physical-chemical tested were temperature, moisture content, $\mathrm{pH}, \mathrm{C}: \mathrm{N}$ ratio, and nutrients contents for $\mathrm{N}, \mathrm{P}$ and $\mathrm{K}$. The temperature on the first day rose to $50.9^{\circ} \mathrm{C}$ in day 13 and decreased to the ambient temperature of $33.5^{\circ} \mathrm{C}$. The moisture content of the compost, was maintained at 50 to $53.3 \%$. For the $\mathrm{C}: \mathrm{N}$ ratio, the initial compost process was 30 and decreased to 19.8 at the end. The content of nutrient of N, P and $\mathrm{K}$ were recorded at $2.3 \%, 0.46 \%$ and $2.67 \%$ and recorded low heavy metal content.

Composting of rice straws (RS), wheat straws (WS), potato plants (PP) and mustard stovers (MS) with fish pond bottom was conducted by Karak et al. [15]. This composting process was conducted for 56 days by using a heap as compost box, with the dimension of $2.5 \mathrm{~m} \mathrm{x} 1.5 \mathrm{~m} \mathrm{x} 1.5 \mathrm{~m}$. For all of the compost preparations, the temperature of compost at the first day ranged from 24 to $26.8^{\circ} \mathrm{C}$ and increased to $81^{\circ} \mathrm{C}$ before becoming constant. The initial values of the $\mathrm{pH}$ ranged from 6.76 to 7.68 while the total $\mathrm{N}$ concentrations were in the range between $14.56 \mathrm{~g} / \mathrm{kg}$ to $21.57 \mathrm{~g} / \mathrm{kg}$; the heavy metal concentration was below the standard set by the Indian Ministry of Agriculture and Cooperation. At the end of the composting, the $\mathrm{C}: \mathrm{N}$ ratio varied from 11 to 18 .

In addition, Tripetckul et al. [16] conducted the composting of wastes that were produced from the coconut plants which are coir pitch and coconut juice. The ratio was 3 (coir pitch):1 (rice bran) :0.08 
(Mollases) with cow manure. Three composts were prepared for this study, the initial C:N ratios were 30,25 and 20 and the moisture content was retained between 50 to $60 \%$. Coconut juice was used to adjust the moisture content. During the composting process, the textures, color, odor and microbial evaluation were observed by visualizations. On day 1, white fungi appeared. At the 2nd and 3rd week, the composting material was the smallest in size and brownish in color and at the end of the composting process, the compost became blackish brown in color and turned into a humus-like texture. In early days of composting, the temperature reached 56 to $58^{\circ} \mathrm{C}$ and the temperature maintained for 9 to 11 days before dropping to the ambient temperature. The pile was turned consistently to increase the oxygen supplies that can help to reactivate the composting process and the availability to microorganisms present during the composting process. The increase of $\mathrm{pH}$ in the beginning, was due to the metabolic degradation of organic acids and ammonification process during organic matter degradations and this slowly declined because of the production of organic acids during the biodegradation of lignocellulose in the compost pile. At the end of the composting process, the $\mathrm{C}: \mathrm{N}$ ratio decreased, this showed that the degree of humification of organic matter had increased through the composting process, while the total $\mathrm{N}$ content increased due to the weight loss of the compost pile.

Other researcher, Janakiram and Sridevi [17] added manure in the composting process and studied the compost of succulent plant, shrubs and trees, mixed with cow dung. The physical and chemical parameters were tested. The moisture contents of the compost were between 12.30 to $18.82 \%$ and $\mathrm{pH}$ values were 7.23 to 7.59 . On the other hand, the $\mathrm{N}$ contents were 1.22 to $1.50 \%, \mathrm{P} 0.32$ to $0.40 \%$ and $\mathrm{K} 1.70$ to $1.8 \%$ and the $\mathrm{C}: \mathrm{N}$ ratios were at $10: 1,11: 1$ and $12: 1$. This study suggested that to increase the presence of $\mathrm{K}$, fibrous materials like straws and wood chips which can absorb the water and prevent loss of $\mathrm{K}$ can be added into the compost.

The study by Saithep et al. [18] used tobacco plants (TP) as their composting wastes. The compost seed was made out of TP (100), cow manure (10), urea fertilizer (2) and compost inoculums (0.1). The moisture content was maintained at $60 \%$. The Bacillus, Streptomyces and Aspergillus bacterias were present in the compost inoculum. The composting process was done by pilling the compost and the aeration of the compost was supplied by manual turning and forced aeration. During the composting process, the temperature ranged between 29 to $62{ }^{\circ} \mathrm{C}$ and decreased slowly to the ambient temperature of $30^{\circ} \mathrm{C}$. The $\mathrm{pH}$ values of the composts during the manual turning and forced aeration were 9.45 to 11.78 and 9.10 to 10.97 and decreased to 7.78 and 7.80 respectively after 10 days. The moisture contents for the compost was initially at $60 \%$ and decreased to $50 \%$, the decrease of the moisture contents in the compost occurred because of the water evaporation due to the heat generated by microbial reactions. In this study, at the end of composting, the $\mathrm{C}: \mathrm{N}$ ratio after 50 days of composting was recorded at 13 and the C: $\mathrm{N}$ ratio of a matured compost in general is below 20 .

Furthermore, Pagnakorn [11] used banana peels that increasingly becoming a common agricultural waste in Thailand. Banana peels were used as a fermented organic liquid. During this compost run, the $\mathrm{pH}$, moisture, organic carbons and nutrients $(\mathrm{N}, \mathrm{P}, \mathrm{K})$ were tested and compared with the standard level set by the Ministry of Agriculture and Cooperative. The $\mathrm{pH}$ value obtained was higher than 7, which was 9.91, this is unsuitable and not recommended because it may cause the soil to loss its efficient nutrients such as iron and manganese. However, this is suitable for the soils in Thailand. The moisture content recorded was $15.55 \%$, while the $\mathrm{N}, \mathrm{P}$ and $\mathrm{K}$ levels were higher than than standard level; $1.69 \%, 2.92 \%$ and $0.84 \%$ respectively.

\subsection{Municipal solid waste}

Manohara and Belagali [19] study the composting quality during three of the monsoons which are premonsoon, monsoon and post-monsoon. During the composting, water and bio-inoculum were added to maintain the moisture contents of the pile. The maximum temperature was recorded at $68{ }^{\circ} \mathrm{C}$, high temperature is important to remove the weed seeds and eliminating the presence of pathogens in the solid wastes. The $\mathrm{pH}$ values were 6.88 to 7.67 as for the moisture content 44 to $64 \%$, organic carbon 
and nutrients $(\mathrm{N}, \mathrm{P}, \mathrm{K})$ were $1.75 \%, 3.4 \%$, and $0.57 \%$ respectively. As for the heavy metal, copper was $700 \mathrm{ppm}$, zinc was $630 \mathrm{ppm}$, lead was $34 \mathrm{ppm}$, chromium was $69 \mathrm{ppm}$ and nickel was $23 \mathrm{ppm}$.

On the other hand, composted wast0es was also Rawat et al. [20] in Ahmadebad, Bangalore and Delhi in India. The compost values were compared to the Indian Standard. Through the composting, the moisture contents were between 23.83 to $31.61 \%$. The moisture content for the compost was insufficient, but turning the compost periodically had fasten the process of composting. The $\mathrm{pH}$ values were 7.82 to 8.19 and the $\mathrm{C}: \mathrm{N}$ ratios were 18.99 to 25.36 . The $\mathrm{N}$ and $\mathrm{P}$ contents were 0.85 to $1.13 \%$ and 2.52 to $2.9 \%$ respectively. While the heavy metal contents, copper, chromium, nickel, lead and cadmium were recorded to be less than the standard provided which were $300 \mathrm{mg} / \mathrm{kg}, 50 \mathrm{mg} / \mathrm{kg}, 50$ $\mathrm{mg} / \mathrm{kg}, 100 \mathrm{mg} / \mathrm{kg}$ and $5 \mathrm{mg} / \mathrm{kg}$ respectively. It is suggested that to increase the quality of the compost, adding cowdung, bagasse and garden wastes was recommended.

In addition, studied compost as the mean for waste management Syamala and Belagali [5] at MySore, Karnataka, India. During the composting, the $\mathrm{pH}$ values recorded were between 7.13 to 8.76 and the moisture content decreased from 85.19 to $29.87 \%$ due to high evaporation rates. The $\mathrm{pH}$ values were between 7.13 to 8.76 , which were higher than normal range due to production of carbon dioxide $\left(\mathrm{CO}_{2}\right)$ from organic acids and the loss of $\mathrm{N}$. The total organic carbon (TOC) decreased throughout the composting process and this was related to the decomposition of waste by microbial populations. The heavy metal concentration was compared to Ohai EPA. There are presence of copper, cadmium, lead and mercury varied between 146.8 to $325 \mathrm{mg} / \mathrm{kg}, 0.1$ to $1.4 \mathrm{mg} / \mathrm{kg}, 1$ to 8 $\mathrm{mg} / \mathrm{kg}$ and 0 to $3 \mathrm{mg} / \mathrm{kg}$ respectively.

\subsection{Kitchen wastes}

Kitchen waste mostly generates food scraps for disposal. Throwing this scraps can create odor problems and adds to the volume of waste going to landfills. There are three methods of composting kitchen wastes were reviewed. As for the composting of kitchen waste, Pathak et al. [21] used biocomposter as a composted and the study was conducted for 4 years, from 2008 to 2011 for 135 days per year.

The highest temperature recorded was $64^{\circ} \mathrm{C}$ and decreased to $32.7^{\circ} \mathrm{C}$ at the ambient temperature, the moisture content was observed at $55.8 \%$ and decreased to $21.7 \%$ at day 36 . The loss of moisture content was due to the high temperature. For the $\mathrm{pH}$, an acid $\mathrm{pH}$ was recorded during the early days of composting due to the production of organic acids, the $\mathrm{pH}$ rose up to 8.6 but later dropped to 6.3. This was caused by the ammonification and mineralization of the organic matters through the activities of microorganisms. For composition of the nutrients N, P, K were between 1.16 to $1.20 \%, 0.03$ to $0.053 \%$ and 0.30 to $0.38 \%$ respectively, as for heavy metals, the content were, copper (45.25 to 48.39 $\mathrm{mg} / \mathrm{kg}$ ), zinc (51.1 to $54.4 \mathrm{mg} / \mathrm{kg}$ ) and iron (1134.8 to1274.2 mg/kg). On the other hand, Gautam et al. [22] mixed vegetables and fruit wastes for their studies. A heap 4' high and 8' long was use as a composted area.

The ambient temperature was recorded, which was between 35 to $45^{\circ} \mathrm{C}$. The initial moisture content was maintained at 50 to $60 \%$. Periodical turning was conducted to aerate the compost heap every 3 to 5 days. The maximum temperature recorded at was between 48 to $50{ }^{\circ} \mathrm{C}$ on the 3 days of the composting process. The moisture content and $\mathrm{pH}$ were between 25 to $41 \%$ and 7.75 to 7.84 respectively. For N, P and K contents, they ranged from 0.03 to $0.07 \%, 0.002$ to $0.005 \%$ and 0.32 to $0.36 \%$ respectively. However, the $\mathrm{N}$ concentration was inadequate when compared to the standard concentration. Hence, this study suggested adding phosphoric acid to avoid the unnecessary volatilization of ammonia.

In another study, Arslan [8] used in-vessel composter as a method to compost kitchen wastes. The composting process was conducted for 22 days. The compost was mixed with $2 \mathrm{~kg}$ of sludges as inoculum and $3.5 \mathrm{~kg}$ of sawdust. The temperature was recorded at $55^{\circ} \mathrm{C}$ on day 2 and this temperature maintained at day 7. The initial $\mathrm{pH}$ value was 5.5 and moisture contents were between 48 to $53 \%$. The $\mathrm{C}: \mathrm{N}$ ratio decreased from 35.92 to 19.69 while the total Kjeldahl Nitrogen (TKN) had increased at the end of composting from 1.43 to $2.45 \%$. As for the heavy metal contents- chromium, cadmium, zinc, 
copper, iron and nickel contents were tested. The cadmium concentration was below the detection limit and the others were $22.4 \mathrm{mg} / \mathrm{kg}, 190.7 \mathrm{mg} / \mathrm{kg}, 35 \mathrm{mg} / \mathrm{kg}, 2641.75 \mathrm{mg} / \mathrm{kg}$ and $15.33 \mathrm{mg} / \mathrm{kg}$ respectively.

\section{Conclusion}

Based on extensive literature review, composting research of different types of organic wastes shown different performance on the effectiveness of the composting process. Composting, as a treatment of organic waste, had been proven to significantly reduce the volume of wastes in the country. In addition, composting can also provide nutrients that are suitable for agriculture and can be used as fertilizer to replace chemical fertilizer. Furthermore, compost can also be used as soil amendments as well as being eco-friendly, hygienic economical and toxic free. In conclusion, during the composting of agricultural wastes the addition of animal manure can enhance the degradation process, whilst in the composting of municipal solid waste and kitchen waste it is important to measure the heavy metal content because of its toxicity and different method of composting influenced the nutrient status of compost. Nevertheless, the compost provided must comply with the standard limit to ensure the quality of the compost.

\section{References}

[1] A. Abd Hamid, A. Ahmad, M.H. Ibrahim, N. Nik Abdul Rahman, Food waste management in Malaysia - current situation and future management option, J. of Industrial Research and Technology, 2(1),36-39,(2012).

[2] Y. Dhokhikah, Y. Trihadiningrum, Solid waste management in asian developing countries: Challenges and opportunities, J. of Applied Environmental and Biological Sciences, 2(7), 329335, (2012).

[3] M. Rawat, A.L. Ramanathan and T. Kuriakose, Characteristics of municipal solid waste compost (mswc) from selected indian cities - a case study for its sustainable utilisation, J. of Environmental Protection, 4, 163-171, (2013).

[4] H. Fathi, A. Zangane, H. Fathi, H. Moradi, Municipal solid waste characterization and it is assessment for potential compost production: A Case Study in Zanjan City, Iran, American J. of Agriculture and Forestry, 2(2), 39-44, (2014).

[5] D.C. Shymala, S.L. Belagali, Studies on variations in physico-chemical and biological characteristics at different maturity stages of municipal solid waste compost, Int. J. of Environmental Sciences, 2(4), 1984-1997, (2012).

[6] L. Rama and M. Dr. Vasanthy, Market waste management using compost technology, Int. J. of Plant, Animal and Environmental Sciences, 4(4), 57-61, (2014).

[7] R. Ahmad, G. Jilani, M. Arshad, Z.A. Zahir and A. Khalid, Bio-conversion of organic wastes for their recycling in agriculture: An overview of perspectives and prospects, Annals of Microbiology, 57(4), 471-479, (2007).

[8] E. Iş1 Arslan, Ayhan Ünlü and Murat Topal, determination of the effect of aeration rate on composting of vegetables-fruit wastes, CLEAN - Soil, Air, Water, 39(11), 1014-1021, (2011).

[9] J.C. Hangreaves, M.S. Adl and P.R. Warman, A review of the use of composted municipal solid waste in agriculture, Agriculture, Ecosystems and Environment, 123, 1-14, (2008).

[10] A. Hernandez, H. Castillo, D. Ojeda, A. Arras, J. Lopez and E. Sanchez, Effect of vermicompost and compost on lettuce production, Chilean J. of Agricultural Research, 70(4), 583-589, (2010).

[11] U. Pangnakorn, Valuable added the agriculture waste for farmers using in organic farming groups in Phitsanulok, Thailand, Tropentag 2006 Prosperity and Poverty in a Globalized World Challenges for Agricultural Research, Born, (2006).

[12] M. Risse, Food waste composing: Institutional and industrial applications, (2012) <retrieved from http://extension.uga.edu/publications/files/pdf/B\%201189_3.PDF.> 


\section{MATEC Web of Conferences}

[13]R.T. Abu-Zahra, A. R.Ta'any and A. R. Arabiyyat, Changes in compost physical and chemical properties during aerobic decomposition, Int. J. of Current Microbiology and Applied Sciences, 3(10), 479-486, (2014).

[14]H.Y. Ch'ng, O.H. Ahmed, S. Kassim and N.K. Ab Majid, Co-composting of pineapple leaves and chicken manure slurry, Int. J. of Recycling of Organic Waste in Agriculture, 2(23) ,1-8, (2013).

[15] T. Karak, P. Bhattacharya, R.K. Paul, T. Das and S.K. Scha, Evaluation of compost from agriculture waste with fish pond sediment as bulking agent to improve compost quality, Enviromental Chemistry, 41(7), 711-723, (2013).

[16] S. Tripetchkul, K. Pundee, S. Koonrisuk and S. Akeprathumchai, Co-composting of coir pitch and cow manure: initial $\mathrm{c} / \mathrm{n}$ ratio vs physico-chemical changes, Int. J. of Recycling of Organic Waste in Agriculture, 1(15), 1-8, (2012).

[17] T. Janakiam and K. Sridev, Conversion of waste into wealth: A study in solid waste management, E-J. of Chemistry, 7(4), 1340-1345, (2010).

[18]N. Saithep, S. Dheeranupatana, P. Sumrit, S. Jeerat, S. Boonchalearmkit, J. Wongsanoon, and C. Jatisatienr, Composting of tobacco plant waste by manual turning a forced aeration system., Journal of Science and Technology., 3(2), 248-260, (2009)

[19]B. Manohara, S.L. Belagali, Characterization of essential nutrients and heavy metals during municipal solid waste composting, Int. J. of Innovative Research in Science, Engineering and Technology, 3(2), 9664-9672, (2014).

[20] M. Rawat, A.L. Ramanathan and T. Kuriakose, Characteristics of municipal solid waste compost (mswc) from selected Indian cities - a case study for its sustainable utilisation, J. of Environmental Protection, 4,163-171, (2013).

[21] A.K. Pathak, M.M. Singh, V. Kumara, S. Arya and A.K. Trivedi, Assessment of physicochemical properties and microbial community during composting of municipal solid waste (Viz. Kitchen Waste) at Jhansi City, U.P (India), Recent Research in Science and Technology, 4(4), 1014, (2012).

[22] S.P. Gautam, P.S. Bundela, A.K. Pandey, M.K. Awasthi and S. Sarsaiya, Composting of municipal solid waste of Jabalpur City, Global J. of Environmental Research, 4(1), 43-46, (2010). 